\title{
A Conceptual Framework for the Externalization of Ecological Wisdom: The Case of Traditional Korean Gardens
}

\author{
Aram Min and Ji-Hyun Lee * \\ Graduate School of Culture Technology, Korea Advanced Institute of Science \& Technology, \\ Daejeon 305-701, Korea; ddmin88@kaist.ac.kr \\ * Correspondence: jihyunlee@kaist.ac.kr; Tel.: +82-042-350-2919
}

Received: 30 August 2019; Accepted: 23 September 2019; Published: 26 September 2019

check for updates

\begin{abstract}
With the continuous effort for a harmonious coexistence with nature in human settlement, theories for ecological design and urban sustainability are proposed and developed. However, in 2014, a new concept called 'ecological wisdom' was proposed with the baseline that knowledge of ecological design should be gained from past sustained examples as ecological design problem spaces are unbounded. How can ecological wisdom from designs be acquired for reuse? The purpose of this research is to propose a conceptual framework for the acquisition of ecological wisdom and develop a detailed externalization methodology (a process of making tacit knowledge into explicit knowledge). Then, to see if it works or not, the methodology is applied to private Korean gardens of the Joseon Dynasty, which are renowned for being 'naturalistic'. First, references from knowledge management $(\mathrm{KM})$ are reviewed to claim that externalization step is necessary for the knowledge cycle of ecological wisdom. Then, for externalization, four steps are presented: (1) Case definition; (2) case deconstruction into geometric data and environmental data; (3) similarity calculation for each data types; and (4) matrix correlation between similarity matrices from geometric data and similarity matrices from environmental data. When the above externalization method is applied to 35 cases of private Korean gardens, yearly average temperature and proximity to the nearest river were the most correlated natural factors in terms of architectural spatial relationship in Korean gardens.
\end{abstract}

Keywords: traditional Korean gardens; ecological wisdom; tacit knowledge; externalization; histogram of forces; similarity matrix; matrix correlation

\section{Introduction}

Ecology as the basis of design - any human intervention on nature-has been argued for past half a century [1], and even today, scholars and professionals of design fields have highlighted the importance of integrating natural environment in the design process [2]. Despite these movements to integrate the knowledge from two domains, there still is a gap between the domains of ecology and design with few design cases that successfully incorporate ecological theory into design practice or planning placing human systems or human interventions within the ecosystem, not as a spectator or an object in the ecology [3]. In an attempt to couple ecology and urban design together for urban sustainability, theoretical and practical frameworks have been suggested, such as sustainability science that investigates the interactions between nature and society [4], and an open cycle of ecological design that utilize plant ecology to investigate the transformation of urban designs [5]. However, the above theories are difficult to verify whether or not they are working before their implementation. Furthermore, in most cases, there is no set solution to address sustainability problems, since the problem space itself is unbounded, and they are wicked in nature [6]. 
Recently, a new concept has been suggested called 'ecological wisdom' first appearing in the landscape and urban planning field for urban sustainability [7], and is now expanding among sustainability and urban management research fields [8-11]. The idea suggests that rather than coming up with a novel or an innovative idea for urban sustainability, why not turn toward evidence-based and time-honored ideas and strategies which have already proven to be ecological through time like the Dujiangyan irrigation system, the Staten Island study, and Central Park [7]. It emphasizes the studying of past successful examples that integrate human or human intervention with nature for wisdom which has developed over the years through trial and error, as well as experience and feedback.

This ecological wisdom can be obtained by examining our heritages which are, essentially, designs. For instance, sites that have already been researched in relation to ecological wisdom are the abovementioned Dujiangyan irrigation system that provide "sustained real and permanent good" to the environment [7], the terraced fields of Honghe and Chongqing as a traditional ecological wisdom [12], and the Hongcun UNESCO World heritage site [8]. Additionally, sites that have been identified to be sustainable with climate and environmental solutions through analysis include the traditional Erzurum Houses of Turkey [13], and the earthen architectural heritage of the Iberian Peninsula [14]. These cultural heritages, or vernacular architectures, embrace ecological wisdom as they are all evidence-based, time-honored, and they are artifacts of an individual's or a collective knowledge that has gone through transformation and internalization over time. So far, there has been a lack of research on ecological wisdom from the aspect of the knowledge cycle. In response, in this research, we propose a conceptual framework that integrates the knowledge creation cycle to the process of creation of ecological wisdom identifying a missing step in the existing ecological knowledge-to-wisdom transformation process. Then, we propose a data-driven method to extract ecological wisdom from built heritage. Lastly, the method is applied to a set of cases to confirm the externalization methodology for the acquisition of reusable knowledge from ecological wisdom.

Specifically, traditional Korean gardens are examined as a case of built heritage. There are multiple theories regarding the origin of traditional Korean gardens. One theory suggested by Yoon (1983) [15] proposes that from being highly influenced by the garden designs of China, due to its large and wide cultural influence on surrounding countries, Korea began to show different design strategy beginning in mid-Goryeo Dynasty (1083-1236) with the rise of private gardens. These private garden designs officially showed different design language in late Goryeo Dynasty (1236-1392) with the appearance of new high-ranking officials who lived with an ideology to live harmoniously with nature on the basis of Taoism, the same philosophy adopted by Li Bing, a Chinese engineer of Dujiangyan irrigation system. As a result, the private gardens of these officials were placed in the midst of a mountain slope, with little intervention, on the topography and landscape [15]. During the era that follows the Goryeo Dynasty, Joseon Dynasty, multiple private gardens were designed and implemented, establishing the character of private Korean gardens to be 'naturalistic' [16,17]. Here, the term 'private' excludes governmental gardens, such as palace gardens, temple gardens, and scholar gardens.

According to this origin theory, Korean gardens of the Joseon Dynasty are designed with passive environmental design strategies, the architectural configuration being highly related to the environmental factors of the site. The natural environment, such as the topography, vegetation, and water are taken as it is during the design process causing minimal alteration in the landscape. In other words, the designs are harmonious to the existing environment. This characteristic is an awareness an ecological designer should have during a design process, understanding that "naturally occurring ecosystem processes are partners in design, not obstacles to overcome and dominate" [18]. That being said, private Korean gardens can be considered as the design products with ecological wisdom.

The purpose of this work is to provide a detailed replicable methodology to acquire ecological wisdom from built heritage for sustainable designs, especially in terms of the spatial configuration of architectural components. This paper is divided into two parts. One is the construction of the conceptual framework and analysis process for the acquisition of ecological wisdom, and the other is the implementation of the analysis process on 35 cases of traditional Korean gardens to acquire 
ecological wisdom. By proposing a conceptual framework and by providing an example for acquiring ecological wisdom regarding the configuration of architectural components, other built heritages can be analyzed quantitatively for ecological wisdom or new knowledge which has the potential to guide the design process to be more sustainable or even evaluate current designs.

\section{Construction of Conceptual Framework}

With a set of ecological designs of the same kind (private gardens) from the same era (Joseon Dynasty) embracing a collective ethical and philosophical principle to respect nature, the acquisition of ecological wisdom can be approached from a data-driven method for the application in design practice. However, beforehand, it is important to examine how ecological wisdom is formed. According to Rowley (2006)'s hierarchy model of data-information-knowledge-wisdom (DIKW) [19], wisdom is formulated based on the type of knowledge received, meaning, wisdom is based on the knowledge with the addition of know-how and understandings [20]. In addition, Young (2016) suggests that the source of wisdom is found in knowledge from the compilation of experience and research, collective stories, as well as scientific theories [21]. Likewise, in Yang et al. (2019), a conceptual model of knowledge-to-wisdom transformation is proposed (see Figure 1) [22]. Here, the transformation is viewed from an individual's perspective; how an individual's ecological knowledge (input) becomes ecological wisdom (output) through interaction between experience, self-reflection, and synthesis producing tacit knowledge [22]. In other words, one of the important aspects of ecological wisdom is that ecological knowledge has become wisdom through tacit knowledge [10,11].

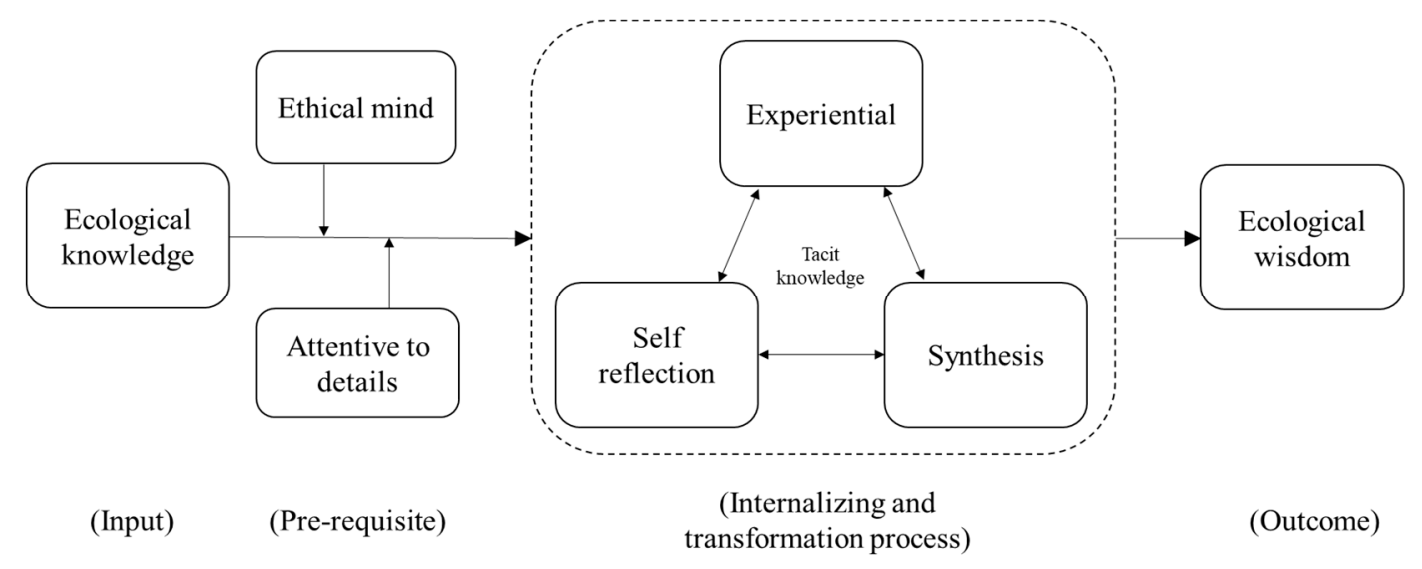

Figure 1. Knowledge-to-wisdom transformation (Redrawn from Yang et al., 2019 [22]).

While the proposed knowledge-to-wisdom transformation model above is linear with knowledge becoming wisdom through tacit knowledge, in knowledge management (KM) research field, there is an emphasis on the acquisition of tacit knowledge or the 'externalization' [23]. It is during externalization that new knowledge is created contributing to innovation [24]. According to Dubberly and Evenson (2011) [25], the process of externalization is a part of a SECI (socialization, externalization, combination, internalization) model that represents knowledge creation first proposed by Ikujiro Nonaka in 1990 (see Figure 2) [26]. 


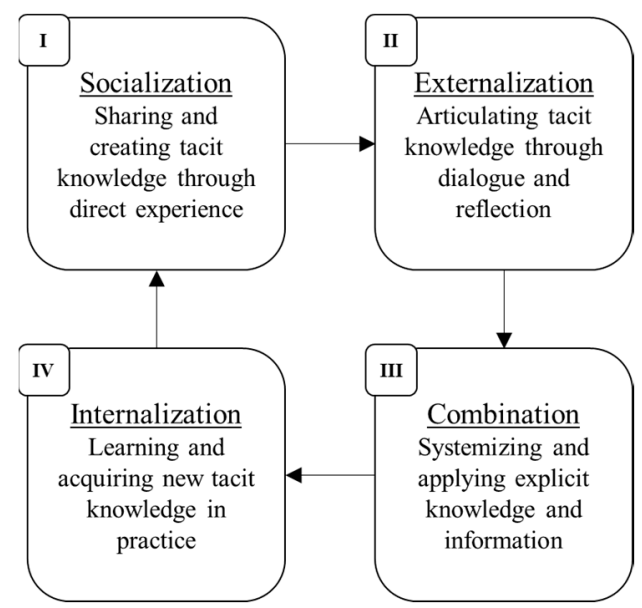

Figure 2. SECI (socialization, externalization, combination, internalization) model (redrawn from Dubberly and Evenson, 2011 [25]).

In the model, externalization is one of the knowledge conversion modes where tacit knowledge is turned into explicit knowledge "so that it can be shared by others to become the basis of new knowledge" [25]. In other words, the knowledge-to-wisdom transformation process needs an externalization process for knowledge creation and innovation, as shown in Figure 3. In this cycle, the ecological knowledge is analogous to a 'combination' of the SECI model-where knowledge is systemized and organized in an individual or a group for application. Then, this explicit knowledge is turned into tacit knowledge through 'internalization' by self-reflection. Next, ecological wisdom is analogous to 'socialization' where formulated tacit knowledge is shared and accumulated through direct experience. Then the tacit knowledge from ecological wisdom is articulated or 'externalized' creating new and explicit concepts. Finally, the cycle completes the loop going back to ecological knowledge where the new knowledge is systemized and organized for application.

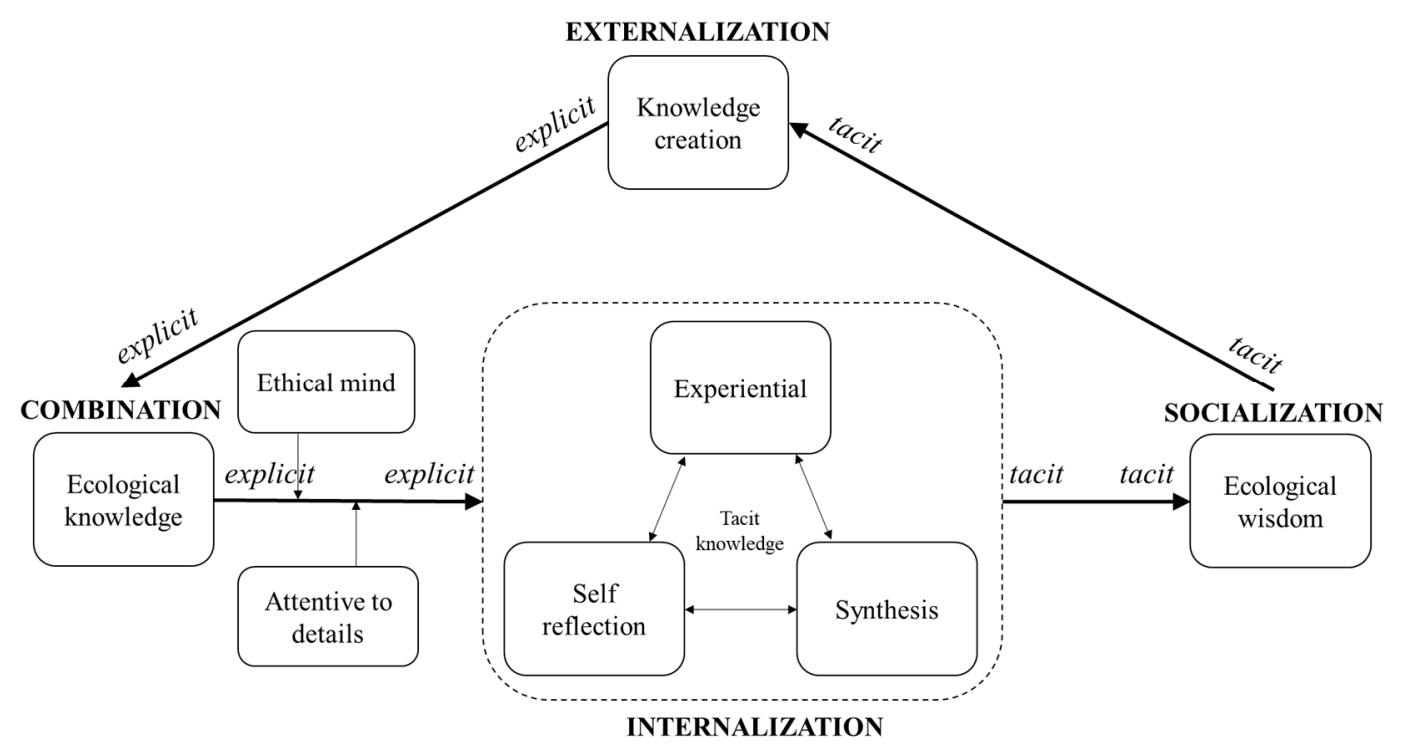

Figure 3. The updated version of knowledge-to-wisdom transformation cycle analogous to the SECI model (modified from Yang et al., 2019 [22]).

Through this analogy, it is clear that the process of externalization is theoretically proven to be essential to acquire ecological knowledge. The process of externalization is executed through a simple four-stage data-driven, and probabilistic approach applicable for externalizing tacit knowledge of 
ecological wisdom from any set of built heritages explained further in Section 3. In fact, tacit knowledge resides in a collection of data, and once extracted, it can be used like explicit knowledge [27].

\section{Implementation and Results}

The first stage of the proposed analysis process in Figure 4 is the definition of cases that fully represents the shared ecological wisdom of one culture or a group. The second stage is the case deconstruction where every case collected is divided into two groups of information: The geometric data (architectural components) of the cases and the environmental data of the sites in which each case is situated. The first group of information should entail geometric data with two or more close curved 2D shapes, while the second is a set of numeric data. Then, in the third stage, two sets of similarity matrices between the cases are calculated: One set from the geometric data and the other from the environmental data. Finally, in the fourth stage, the correlation between the similarity matrices from the geometric data and the environmental data are calculated to discover how architectural configuration correlates to the natural environment. This analysis methodology is interestingly similar to research methods often used to estimate the evolutionary relationships between individual genes and their genome [28]. This section is divided into four stages of the analysis process (Section 3.1. Case Definition, Section 3.1. Case Deconstruction, Section 3.2. Similarity Calculation, Section 3.3. Matrix Correlation) explaining each step with detailed methodologies, examples, and results using 35 cases of traditional Korean gardens from Joseon Dynasty to acquire ecological wisdom.

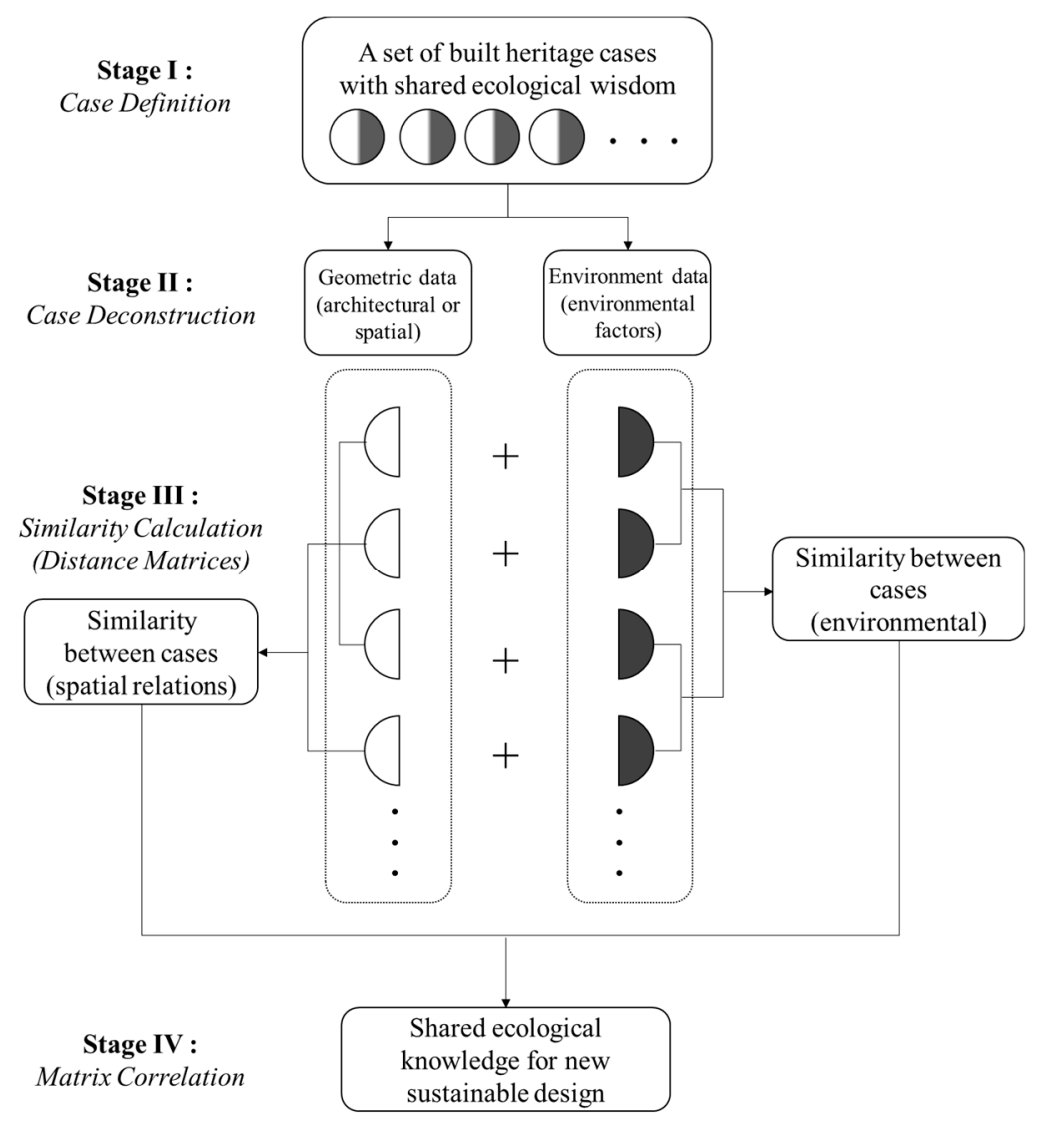

Figure 4. Analysis process for the externalization of ecological wisdom.

\subsection{Case Definition}

A boundary for the traditional Korean garden is vague, and a full list of gardens has never been made. Therefore, for this research, the primary source entitled Field Note of Korean Gardens is used [29]. This book is written by three Korean landscape architecture professors, including detailed 
explanations of garden components along with pictures and plans in scale. In addition, an official report from the Presidential Commission on Architecture Policy is used to create a list of traditional Korean gardens [30]. From these primary sources, the list of Korean gardens is made even clearer by limiting the gardens from Joseon Dynasty and by eliminating gardens of temples, palaces, and scholarly schools as characteristics of Korean gardens are often observed in private individual's gardens [15]. Therefore, garden types included in the database are house gardens, pavilion gardens, annex gardens, and rural villa gardens ending up with a total of 35 garden cases (see Table 1). Under these criteria, the 35 cases listed in Table 1 are representative of private Korean gardens of Joseon Dynasty.

Table 1. Full list of gardens.

\begin{tabular}{|c|c|c|c|c|c|}
\hline $\begin{array}{l}\text { Index } \\
\text { Number }\end{array}$ & $\begin{array}{c}\text { Shortened English } \\
\text { Name }\end{array}$ & $\begin{array}{l}\text { Index } \\
\text { Number }\end{array}$ & $\begin{array}{c}\text { Shortened English } \\
\text { Name }\end{array}$ & $\begin{array}{l}\text { Index } \\
\text { Number }\end{array}$ & $\begin{array}{c}\text { Shortened English } \\
\text { Name }\end{array}$ \\
\hline 1 & Aseokheon & 13 & Nogudang & 25 & Ullimsanbang \\
\hline 2 & Cheongamjeong & 14 & $\begin{array}{c}\text { Oeam Village Kyosu } \\
\text { House }\end{array}$ & 26 & Unjoru \\
\hline 3 & Dongnakdang & 15 & $\begin{array}{c}\text { Oeam Village } \\
\text { Songwha House }\end{array}$ & 27 & $\begin{array}{c}\text { Woo Kyu Dong } \\
\text { House }\end{array}$ \\
\hline 4 & $\begin{array}{l}\text { Exile Residence of } \\
\text { Jeong Yakyong }\end{array}$ & 16 & $\begin{array}{l}\text { Oeam Village } \\
\text { Yeongam House }\end{array}$ & 28 & $\begin{array}{c}\text { Woodland Garden of } \\
\text { Choganjeong }\end{array}$ \\
\hline 5 & Gwanghallu & 17 & Okhojeong & 29 & $\begin{array}{c}\text { Woodland Garden of } \\
\text { Imdaejeong in } \\
\text { Hawsun }\end{array}$ \\
\hline 6 & Ildu Historic House & 18 & Samgaheon & 30 & Myeongokheon \\
\hline 7 & $\begin{array}{l}\text { Jeong Yongjun } \\
\text { House }\end{array}$ & 19 & Seobaekdang House & 31 & $\begin{array}{c}\text { Woodland Garden of } \\
\text { Yun Seondo }\end{array}$ \\
\hline 8 & Kim Dongsu House & 20 & Seokpajeong & 32 & $\begin{array}{l}\text { Yeo Gyeonggu } \\
\text { House }\end{array}$ \\
\hline 9 & Kim Gieung House & 21 & Seonglakwon & 33 & Yi Yonguk House \\
\hline 10 & Mongsimjae & 22 & Seongyojang & 34 & Yongho Garden \\
\hline 11 & Mugyeondang & 23 & Seoseokji & 35 & Imcheonggak \\
\hline 12 & $\begin{array}{c}\text { Myeongjae Historic } \\
\text { House }\end{array}$ & 24 & Soswaewon & & \\
\hline
\end{tabular}

\subsection{Case Deconstruction}

The listed cases in Section 3.1 are divided into two groups of information: Geometric, and environmental. This section explains the methods used to extract and quantify the data. It also discusses how it was collected, and where it was collected from.

\subsubsection{Geometric Data}

By using the blueprints of the 35 gardens, obtained from books and online, as well as a literature review of all the gardens, the components of each garden were listed in Korean, and then translated into English-focusing on the function of the components. The garden components that are vaguely explained or do not have identification are disregarded. After the components were listed and translated from all 35 gardens, the frequency of the components was as is shown in Table 2. Then, excluding the components with the frequency of one (since this research examines the similarity of garden configuration using the spatial relations of garden components) the remaining 16 components are grouped into six functional groups: Residential building (RB), functional building (FB), leisure building (LB), yard (YA), pond (PO), artificial hill (AH). For instance, main building, reception building, annex, and separate quarter are grouped into residential building $(\mathrm{RB})$, entrance quarter, shrine, storage 
quarter, servants' quarter, and mid-gate servants' quarter are grouped into functional building (FB), pavilion is categorized as leisure building (LB), inner yards, reception yards, backyards, outer yards are all grouped into yard (YA), ponds (PO) and artificial hills (AH) are as they are.

Table 2. Architectural components, frequencies, functional groups, and example images.

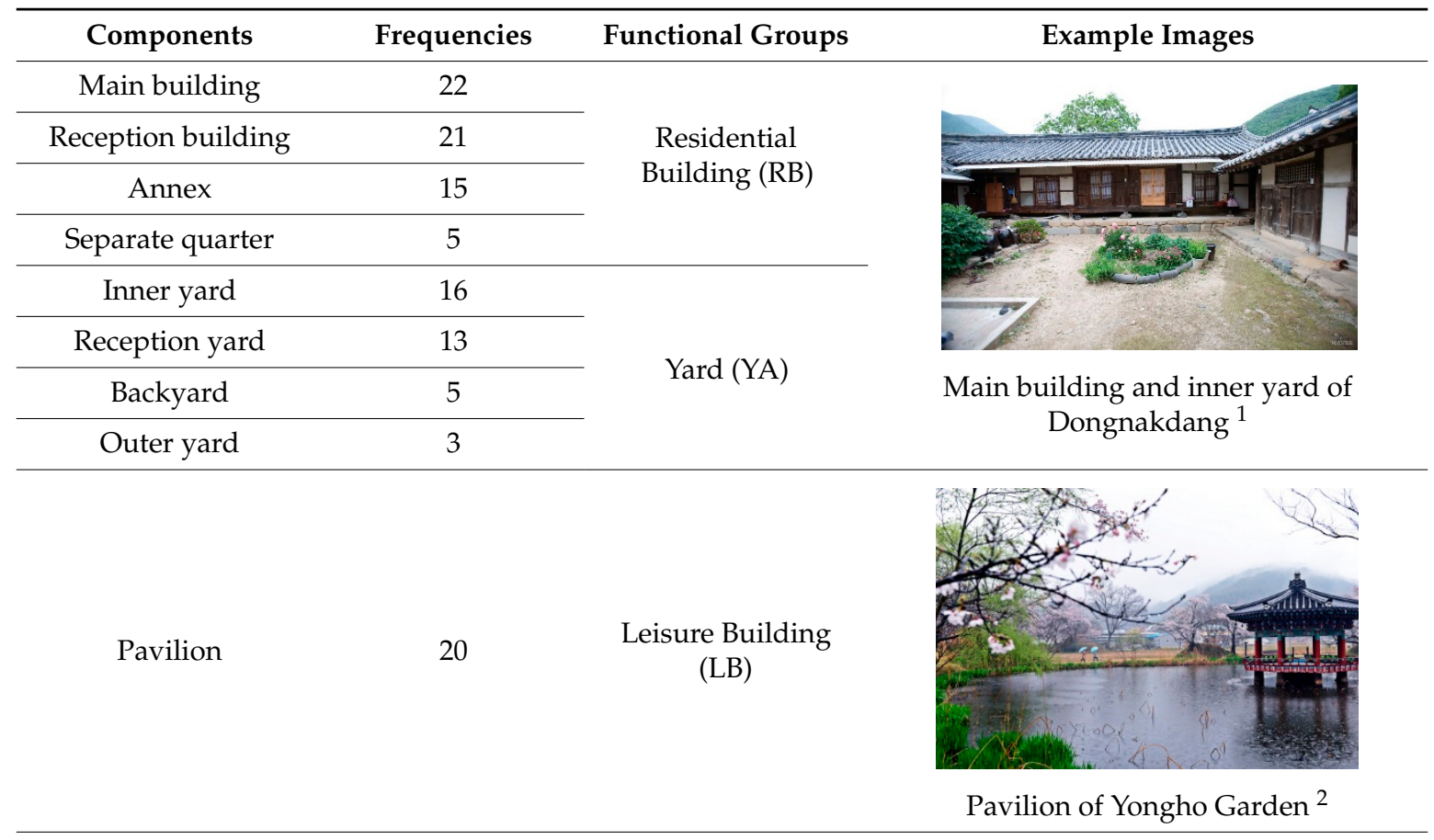

\begin{tabular}{|c|c|c|c|}
\hline Entrance quarter & 16 & \multirow{5}{*}{$\begin{array}{l}\text { Functional } \\
\text { Building (FB) }\end{array}$} & \\
\hline Shrine & 14 & & \\
\hline Storage quarter & 14 & & \\
\hline Servants' quarter & 9 & & \\
\hline $\begin{array}{l}\text { Mid-gate servants' } \\
\text { quarter }\end{array}$ & 7 & & Servants' quarter of Kim Dongsu House ${ }^{3}$ \\
\hline Pond & 25 & Pond $(\mathrm{PO})$ & \\
\hline \multirow[t]{2}{*}{ Artificial hill } & 14 & Artificial Hill (AH) & \\
\hline & & \multicolumn{2}{|r|}{ Pond and artificial hill of Mugyeondang 4} \\
\hline
\end{tabular}

Then, these components from 35 gardens are digitized in scale and color-coded according to their functional groups using a CAD program with North directing upward. Residential buildings (RB) are indicated in red, ponds (PO) in blue, functional buildings (FB) in brown, leisure buildings (LB) in green, yards (YA) in yellow, and lastly, artificial hills (AH) in black. Then the simplified plans are exported as $500 \times 500$-pixel JPG files. The thumbnail diagrams of all 35 gardens are represented in Figure 5 . 


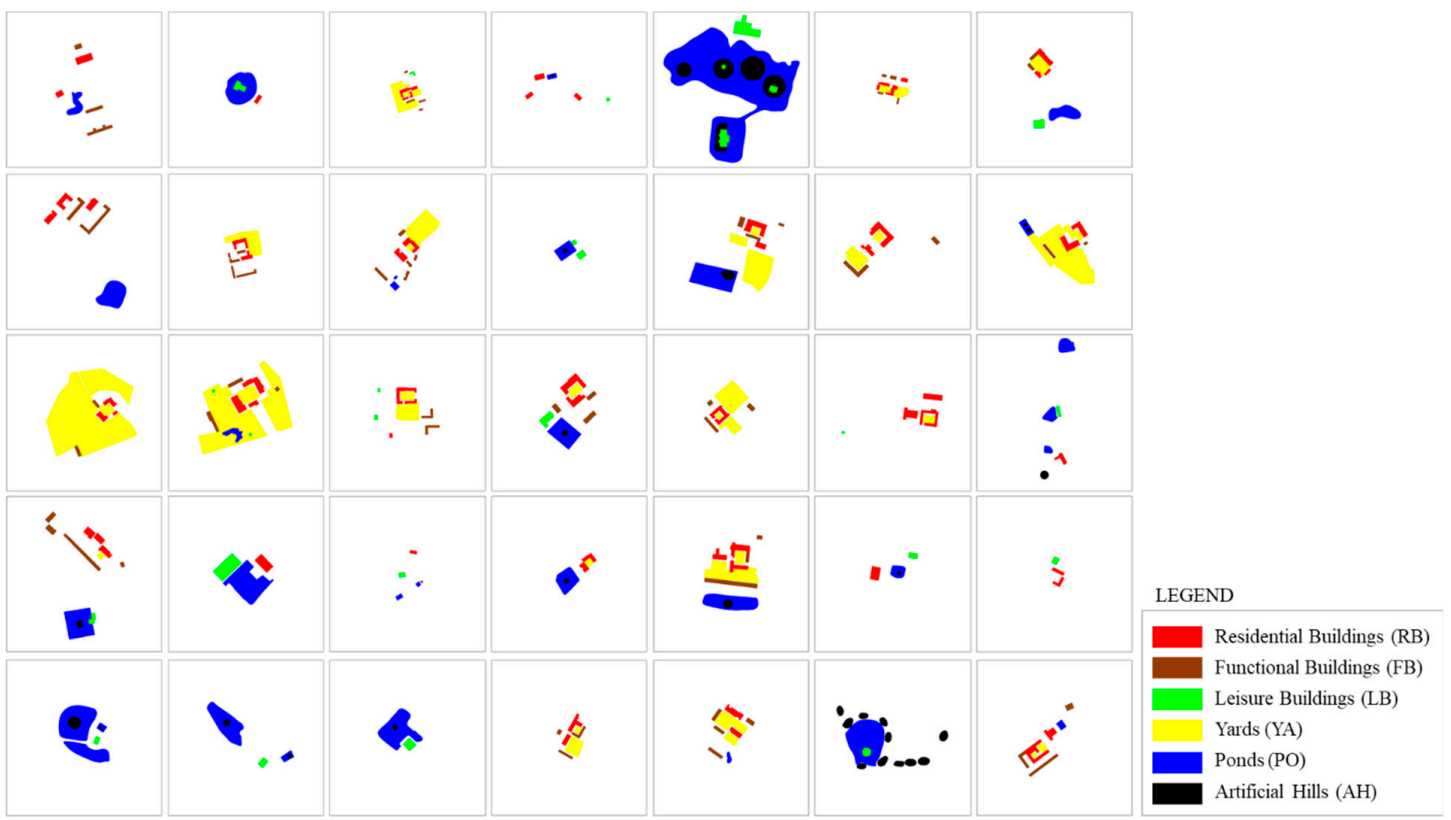

Figure 5. Color-coded plan diagrams of 35 gardens.

In order to measure the similarity between the gardens in terms of these color-coded plan diagrams, quantification is necessary. While various spatial quantification methods and scene quantification methods exist from the field of robotics, architecture, and geology [31-34], for this research, an algorithm that measures the spatial relations between objects is used called the Histogram of Forces (HoF). It is a method developed first to understand the spatial organization of regions in images representing the spatial organization of scenes into histograms that entail information on the shape of the objects, orientation, size, and distance between two objects [35]. For this research, the HoF is applied at a "low-level" representing spatial relationship between pairs of objects into a histogram for similarity measures. Given two objects A and B-A is the argument object and B is the reference object (object A is situated in relation to object $\mathrm{B})-\mathrm{HoF}$ is calculated using the Equation (1):

$$
F^{\mathrm{AB}(\theta)}=\int_{-\infty}^{+\infty} F\left(\theta, \mathrm{A}_{\theta}(v), \mathrm{B}(v)\right) d v .
$$

This equation can be understood by looking at Figure 6. Basically, HoF algorithm begins with randomly placed starting points on object $\mathrm{B}$ (referent) and extending vectors from the points at incremental degrees. When intersections are made to object $\mathrm{A}$ (argument), the vectors are segmented with multiple endpoints on the intersected sections of the vectors. Then, the lengths of the segments are added [36]. Since histograms represent frequency, if the object A is large, meaning the lengths of the intersecting vectors are long, there will be more endpoints resulting in a higher sum value of the segment lengths. Furthermore, when two objects of the same size are placed near to each other, then the force value will be high because $\mathrm{HoF}$ is inversely proportioned to the distance between two objects. There are two ways to represent the relative positions of two objects in the HoF algorithm. One is to use the constant force $(F 0)$ meaning distance between objects are just treated as is and the other is to use the gravitational force (F2) which squares the distance to focus on the closest parts. For this research, to emphasize the distance between objects, the algorithm for the histogram of gravitational forces is used. Through $\mathrm{HoF}$ the spatial relations between two objects can be quantitatively represented. In fact, in one of the researches that apply HoF, types of airports were predicted using satellite images [37]. 


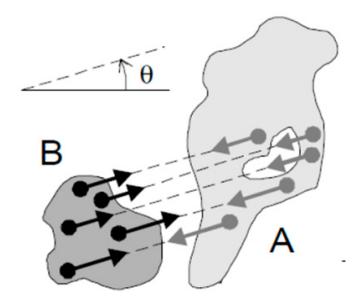

(a)

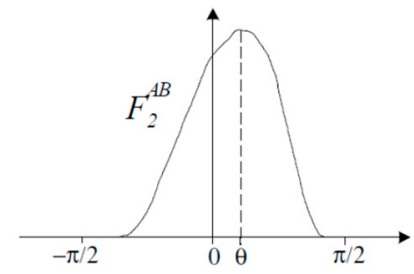

(b)

Figure 6. (a,b) A visual concept of the HoF computation (taken from Matsakis, 2002).

When the HoF algorithm is implemented using MATLAB and is executed on the color-coded diagram plans, the following results can be driven, as shown in Figure 7 taking the first case (Aseokheon) for example. Here, for visibility, the number of points on the reference objects (residential buildings (RB) (red)) and thus, the number of vectors extended are reduced. In Figure 7, the vectors have rotated to 270 degrees showing intersection with a pond (PO (blue)) and functional buildings (FB (brown)), therefore, increasing the force value in the histogram especially for the RBPO relations.
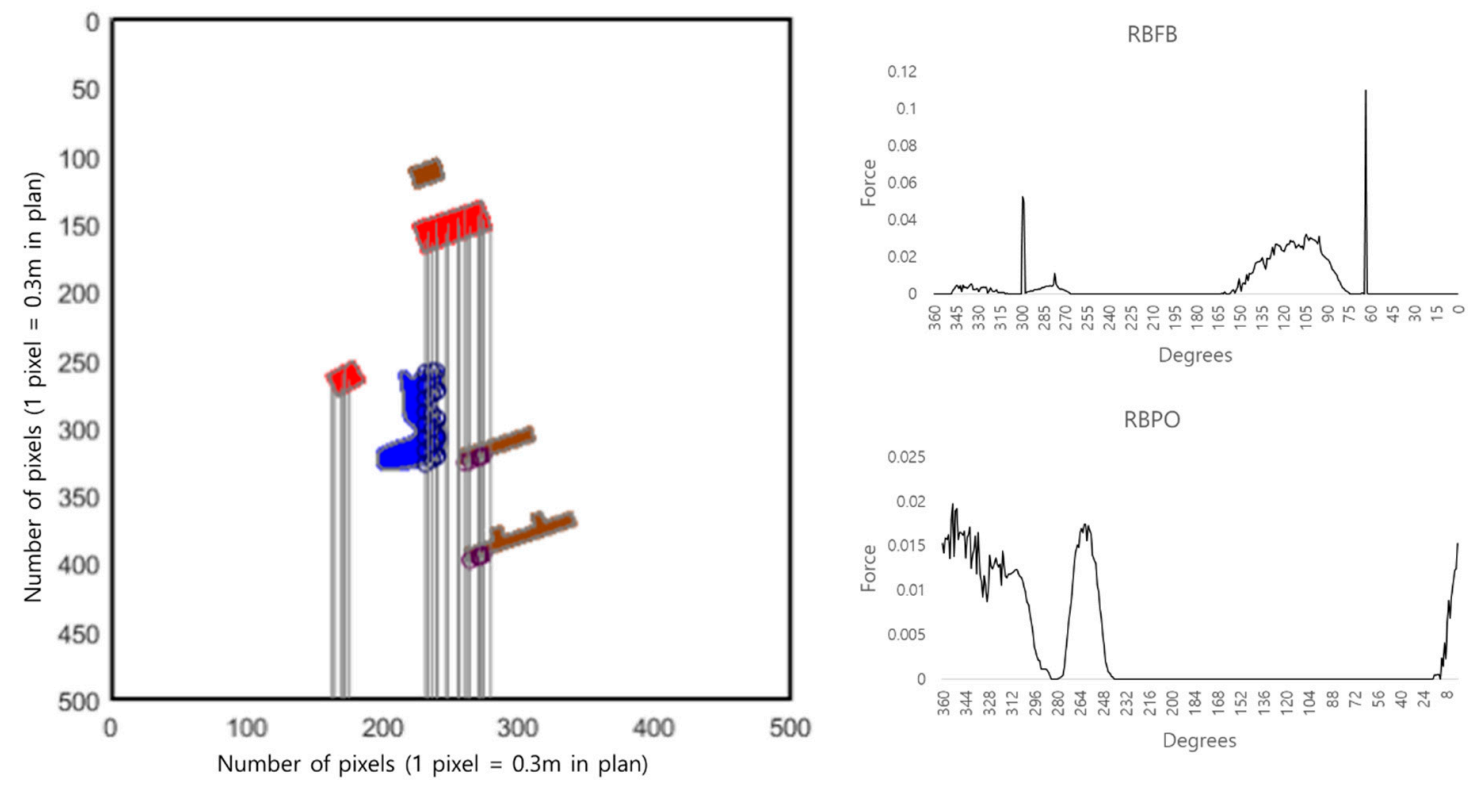

Figure 7. Calculation of HoF using MATLAB.

For all gardens, six groups of components will have a total of 15 histograms for all possible pairs. For those gardens without some components, the values are treated as 0 . In the end, there will be a data frame of 15 by 360 for the force value at each degree for each garden.

\subsubsection{Environmental Data}

In Yang and Li (2016) [38], which studies one of Ian McHarg's most successful project of town development, The Woodlands, Texas as a case of actionable ecological wisdom and uses the following inventory maps for analyzing the landscape: Physiography (elevation and slope), geology, soils, hydrology, vegetation, wildlife, climate, and natural resources. In another research by Mileto et al., (2019) [14], four thematic maps were used: Morphology (altitude and relations with major rivers), climate (rainfall, mean temperature, climate, solar radiation), geology (lithology and seismicity), and society (population density). Likewise, this research collects the following environmental data from appropriate sources (see Table 3). 
Table 3. Environmental factors considered and data sources.

\begin{tabular}{|c|c|c|c|}
\hline $\begin{array}{l}\text { Environmental } \\
\text { Factors }\end{array}$ & Factors & Data Source & $\begin{array}{l}\text { Data Gathering } \\
\text { Methodology }\end{array}$ \\
\hline \multirow{3}{*}{ Physiography } & Elevation & \multirow{3}{*}{$\begin{array}{c}\text { Digital map (1:25,000) provided by the } \\
\text { National Geographic Information Institute, } \\
\text { accessed via National Spatial Data } \\
\text { Infrastructure Portal [39] }\end{array}$} & \multirow{3}{*}{$\begin{array}{c}\text { Select and export Contour } \\
\text { layers }->\text { 3D analyst tools }-> \\
\text { data management }->\text { create } \\
\text { TIN }\end{array}$} \\
\hline & Slope & & \\
\hline & Aspect & & \\
\hline \multirow[b]{2}{*}{ Geology } & $\begin{array}{l}\text { Usable soil } \\
\text { depth }\end{array}$ & \multirow{2}{*}{$\begin{array}{c}\text { Thematic map provided by the National } \\
\text { Institute of Agricultural Sciences, accessed } \\
\text { via National Spatial Data Infrastructure } \\
\text { Portal [39] }\end{array}$} & \multirow{2}{*}{$\begin{array}{c}\text { Identifying attribute data from } \\
\text { the thematic maps using } \\
\text { ArcGIS }\end{array}$} \\
\hline & $\begin{array}{l}\text { Amount of } \\
\text { stone in the } \\
\text { soil }\end{array}$ & & \\
\hline \multirow{7}{*}{ Climate } & $\begin{array}{l}\text { Yearly mean } \\
\text { temperature }\end{array}$ & \multirow{6}{*}{$\begin{array}{l}\text { Climate data provided by climate-data.org } \\
\text { which is based on a climate model using } \\
\text { weather data collected between } 1982 \text { and } \\
\qquad 2012 \text { [40] }\end{array}$} & \multirow{6}{*}{$\begin{array}{c}\text { Gathering information for the } \\
\text { location of each garden }\end{array}$} \\
\hline & $\begin{array}{l}\text { Lowest } \\
\text { temperature }\end{array}$ & & \\
\hline & $\begin{array}{l}\text { Lowest mean } \\
\text { temperature }\end{array}$ & & \\
\hline & $\begin{array}{l}\text { Highest } \\
\text { temperature }\end{array}$ & & \\
\hline & $\begin{array}{l}\text { Highest mean } \\
\text { temperature }\end{array}$ & & \\
\hline & Yearly rainfall & & \\
\hline & $\begin{array}{l}\text { Solar } \\
\text { radiation }\end{array}$ & $\begin{array}{c}\text { Digital map }(1: 25,000) \text { provided by the } \\
\text { National Geographic Information Institute, } \\
\text { accessed via National Spatial Data } \\
\text { Infrastructure Portal [39] }\end{array}$ & $\begin{array}{c}\text { Select and export Contour } \\
\text { layers -> TIN -> raster -> Area } \\
\text { solar radiation tool in Spatial } \\
\text { Analyst Tool of ArcGIS, } \\
\text { data/time setting } 1800, \text { start } \\
\text { day } 1 \text {, end day } 365\end{array}$ \\
\hline \multirow[b]{2}{*}{ Hydrology } & $\begin{array}{l}\text { Proximity to } \\
\text { nearest river }\end{array}$ & \multirow{2}{*}{$\begin{array}{l}\text { Digital map }(1: 25,000) \text { provided by the } \\
\text { National Geographic Information Institute, } \\
\text { accessed via National Spatial Data } \\
\text { Infrastructure Portal [39] }\end{array}$} & \multirow{2}{*}{$\begin{array}{c}\text { Select and export river and } \\
\text { stream layers -> Near tool in } \\
\text { the proximity of analysis tools } \\
\text { in ArcGIS }\end{array}$} \\
\hline & $\begin{array}{l}\text { Proximity to } \\
\text { the nearest } \\
\text { stream }\end{array}$ & & \\
\hline
\end{tabular}

\subsection{Similarity Calculation}

This section is also divided into two subsections with sets of data: One geometric, and the other environmental. For each, the data collected above are used to calculate the similarity matrices between cases. The similarity calculation methods are explained, and the most similar and the least similar cases are illustrated.

\subsubsection{Geometric Data}

In order to calculate the similarity between histograms, a Sørensen similarity algorithm [41], " $2 w /(A+B)$ ", is used as illustrated in Figure 8. While A is the total area under one histogram and B is the total area under another histogram, $\mathrm{w}$ is the overlap (intersection) of the two areas.

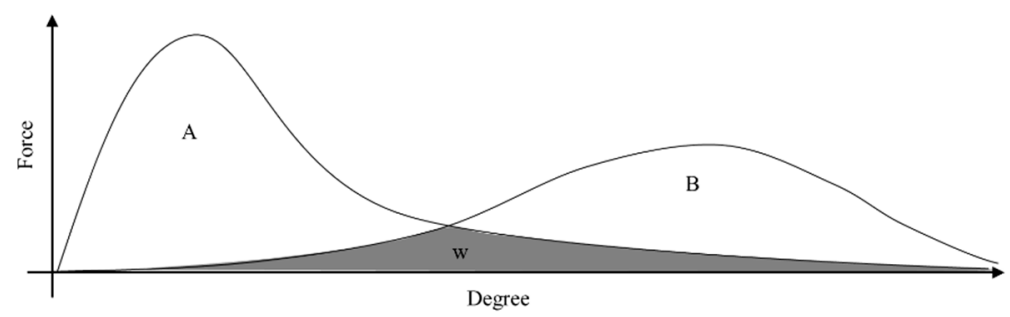

Figure 8. Histogram similarity measure (Sørensen similarity) (Redrawn from [41]). 
In this research, the gardens Mongsimjae and Yi_Yonguk_House have the highest similarity value of 0.87 for RBPO relationship and when all similarity values are averaged, the gardens Kim_Gieung_House and Seobaekdang_House are found to be the most similar with a similarity value of 0.53 , as shown in Figure 9 . In the end, there were 15 similarity matrices.
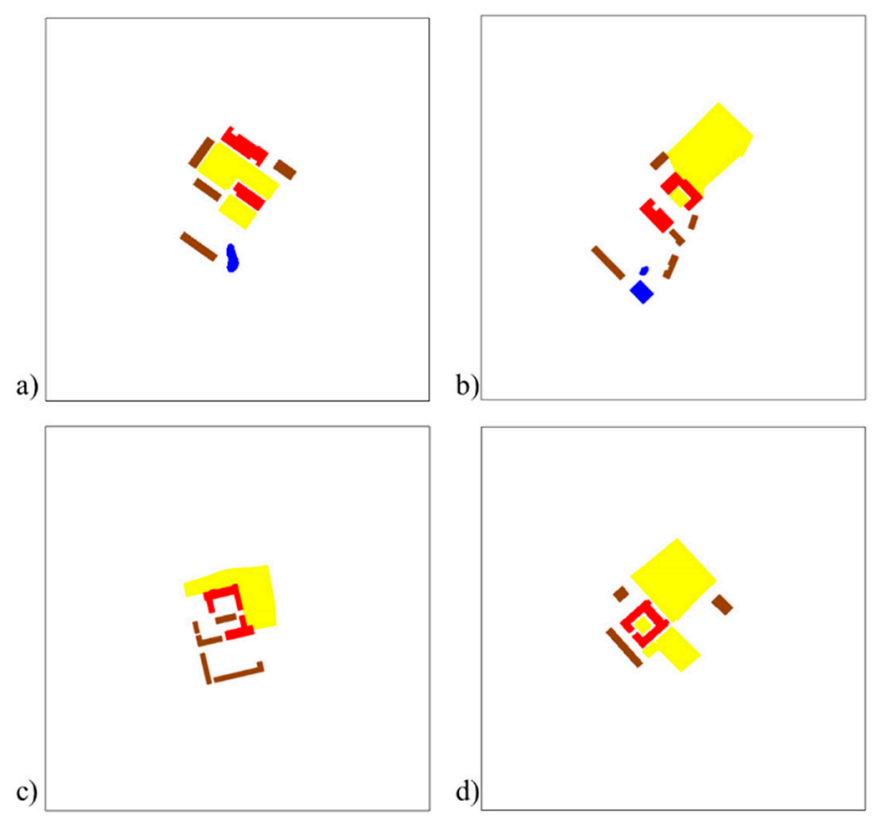

Figure 9. Cases with high similarity measures. (a) Mongsimjae and (b) Yi_Yonguk_House have a similarity value of 0.87 for RBPO spatial relationship. (c) Kim_Gieung_House and (d) Seobaekdang_House have a similarity value of 0.53 overall.

\subsubsection{Environmental Data}

The character of the data alters the ways one could calculate the similarity between two gardens for each of the environmental factor. For instance, for the environmental factor data without a value of 0 (all except slope and aspect) Equation (2) is used where the minimum value of the two environment values, $\mathrm{A}$ and $\mathrm{B}$, from two gardens are divided using the average value of the two values,

$$
\operatorname{sim}_{\mathrm{AB}}=\left(\frac{\min (\mathrm{A}, \mathrm{B})}{\operatorname{avg}(\mathrm{A}, \mathrm{B})}\right) \text {. }
$$

Meanwhile, to calculate similarity matrix for gardens regarding the slope, Equation (3) is used because the slope of 0 is a common value, and therefore, above equation is not applicable which results in an undefined value when two gardens have slope values of 0 , while the similarity value should equal to 1. The Equation (3) helps to prevent such error,

$$
\operatorname{SlopSim}_{\mathrm{AB}}=\left(\frac{90-|\mathrm{A}-\mathrm{B}|}{90}\right) .
$$

The aspect values range from 0 to 360 divided by eight sections of directions, each direction with a degree of 45 . For instance, the North is composed of values 0 to 22.5 and 337.5 to 360 . As for flat regions, the value is -1 and is handled as not as a number $(\mathrm{NaN})$ in this research. To calculate the similarity between these values, Equation (4) is used to prevent the same error mentioned above for slope similarity, as well as to measure the similarity between angles,

$$
\operatorname{Aspsim}_{\mathrm{AB}}=1-\left(\frac{\min (|\mathrm{A}-\mathrm{B}|,|\mathrm{A}-\mathrm{B}-360|)}{180}\right) .
$$


In the end, there were a total of 14 similarity matrices.

\subsection{Matrix Correlation}

Now with 15 similarity matrices between 35 gardens for all possible pairs of spatial components (FBAH, FBLB, FBPO, FBYD, LBAH, LBPO, LBYD, POAH, RBAH, RBFB, RBLB, RBPO, RBYD, YDAH, YDPO) and another set of 14 similarity matrices between 35 gardens for each of the environmental factors (aspect, elevation, proximity to nearest river, proximity to nearest stream, yearly rainfall, slope, soil depth, stone amount, yearly average temperature, lowest temperature, average lowest temperature, highest temperature, average highest temperature, solar radiation) the correlation between the matrices are calculated which results in 210 possible pairs.

To calculate the correlation, quadratic assignment procedure (QAP) hypothesis test is performed. The QAP is a method often used in social network analysis when analyzing the correlation between two networks with the same actors [42]. Applying the concept to this research, there are two sets of networks, geometric and environmental, for all 35 gardens or actors, and through QAP we can observe how the probability of similarity matrix between gardens calculated based on geometric data is related to the probability of the similarity matrix calculated based on environmental data (dyadic data). While QAP returns a likelihood association between two matrices identifying significant factors that predict other relations as used by [43], it is especially useful when eliminating spurious structural influence caused by other factors [44]. What QAP algorithm does is it permutes the rows and columns of the matrix the same about 1000 times eliminating any relationship between the dependent variables and the independent variables, but preserving dependence between elements of the same row or columns [45]. The resulting permuted matrix corresponds to the null hypothesis which is that the observed graph-level indices (GLIs), such as degree centralization, connectedness, and a hierarchy of non-permuted matrix is drawn from the distribution of the permuted matrix [46]. For this research, the QAP is conducted using the 'qaptest' function from the 'sna' package in R [47]. In the summary of the test, there are estimated p-values which estimate the probability of observing the test statistic value both higher and lower than the value observed. The qaptest was conducted for all 210 pairs of matrices with the permutation value of 1000, and the pairs that reject the null hypothesis are summarized in Table 4.

Table 4. Significant results of the quadratic assignment procedure (QAP) test.

\begin{tabular}{ccccc}
\hline $\begin{array}{c}\text { Similarity Through } \\
\text { Spatial Relations }\end{array}$ & $\begin{array}{c}\text { Similarity Through } \\
\text { Environment Factors }\end{array}$ & $\begin{array}{c}\text { Test Value } \\
\text { (Correlation) }\end{array}$ & $\boldsymbol{p} \geq$ Observed & $p \leq$ Observed \\
\hline POAH & Aspect & 0.250752491 & $0.007^{*}$ & 0.993 \\
LBPO & Elevation & -0.126622463 & 0.969 & $0.031^{*}$ \\
FBLB & Elevation & -0.126540797 & 0.987 & $0.013^{*}$ \\
LBAH & Elevation & -0.126228002 & 0.972 & $0.028^{*}$ \\
POAH & Highest temperature & -0.188652765 & 0.996 & $0.004^{*}$ \\
LBPO & Highest temperature & -0.153500881 & 0.988 & $0.012^{*}$ \\
RBPO & Lowest temperature & 0.111595 & $0.033^{*}$ & 0.967 \\
FBPO & Proximity to nearest river & 0.133692941 & $0.033^{*}$ & 0.967 \\
FBYD & Proximity to nearest river & 0.157325551 & $0.023^{*}$ & 0.977 \\
RBYD & Proximity to nearest river & 0.161706907 & $0.04^{*}$ & 0.96 \\
RBPO & Proximity to nearest river & 0.168828057 & $0.01^{*}$ & 0.99 \\
RBLB & Proximity to nearest river & 0.171770561 & $00^{*}$ & 1 \\
YDPO & Proximity to nearest river & 0.173023696 & $0.009 *$ & 0.991 \\
RBFB & Proximity to nearest river & 0.209400815 & $0.006^{*}$ & 0.994 \\
FBLB & Solar radiation & -0.118721418 & 0.965 & $0.035^{*}$ \\
LBPO & Stone amount & -0.074773224 & 0.977 & $0.023 *$ \\
RBPO & Yearly average temperature & 0.14263946 & $0.006^{*}$ & 0.994 \\
FBPO & Yearly average temperature & 0.145511537 & $0.013^{*}$ & 0.987 \\
YDPO & Yearly average temperature & 0.146082934 & $0.013^{*}$ & 0.987 \\
\hline
\end{tabular}


The above matrix pairs are those that correlate not by spuriousness. From Table 4 ordered by the similarity through environmental factors, we can observe that proximity to the nearest river and the temperature environment factors have the tendency to correlate to the spatial relations, not by chance. It is interesting to see that physiography factors (such as slope) are not present as much as hydrology and climate factors when authors instinctively thought that these were the most influential for the architectural layout of gardens.

Of the 19 relationships, not all show a clear relationship when visually represented using a 3D plot. For the purpose of this research which is to find underlying ecological wisdom of architectural layout in relation to environmental factors, three of the 19 relations with a trend in relations are chosen for further discussion (see Figure 10). From Figure 10a, we can observe that most of the histogram peaks are in the range of 240 to 280 degrees which means that most of the ponds in Korean gardens are located in the southern direction of residential buildings. However, it is important to point out that with the increase of yearly average temperature, the location of the histogram peak (pond) moves to the western direction of the residential building to the northeastern direction. This implies that for gardens in hotter regions, the ponds are located in the northeastern direction of residential buildings. A possible reason for this tendency is to preserve water level in gardens (avoid evaporation), the ponds are intently placed in the northeastern part of the residential building rather than the southern part which has a higher duration of sunlight (see Figure 11a). As for Figure 10b, we can observe that most gardens situated near a river have ponds either large or near the southern direction of the functional buildings. This can be explained that traditional Korean gardens usually pump water from the river for a natural source of water. As for the direction of its location, it can be explained by examining the characteristics of Korean gardens which are usually located on the south-facing slope of mountains with a collection of water at the lowest point. Furthermore, to accompany such large bodies of water, large yards are located in the northeastern direction of functional buildings, as shown in Figure 10c. The relationship with the functional buildings compared to residential buildings because functional buildings include entrance quarter which divides the outside and the inside of garden through a linear placement of rooms, and as shown in Figure $11 \mathrm{~b}, \mathrm{c}$ the ponds are located outside the building part of the garden.
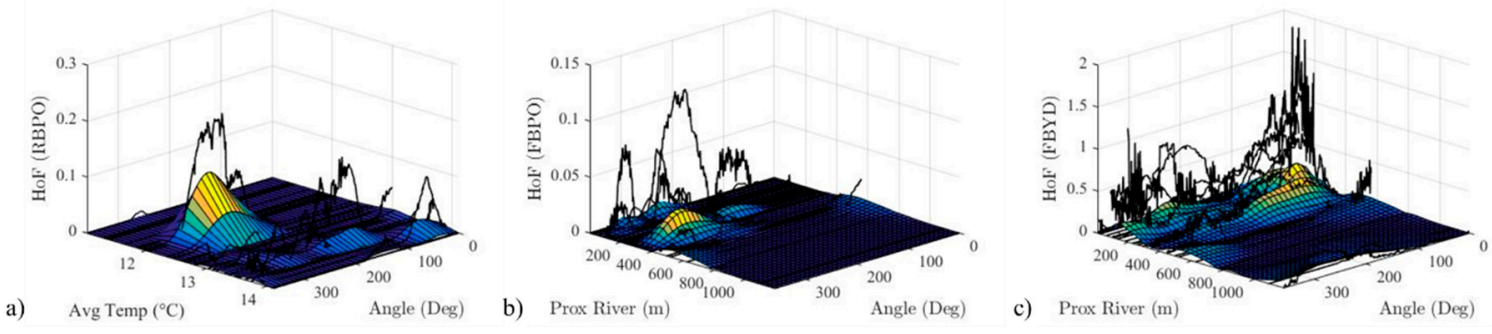

Figure 10. The $3 \mathrm{D}$ plotting showed histograms representing spatial relationships in the sequential order of environmental factor values and lowess smoothing of the curves (smoothing span of 0.05) for visual understanding of the trends. (a) Residential building-pond spatial relations and yearly average temperature (test value $=0.143, p \geq 0.006$ ), (b) functional building-pond spatial relations and proximity to nearest river (test value $=0.134, p \geq 0.033$ ), and (c) functional building-yard spatial relations and proximity to nearest river (test value $=0.157, p \geq 0.023$ ). Histograms are shown in sequential order of environmental factor values. 

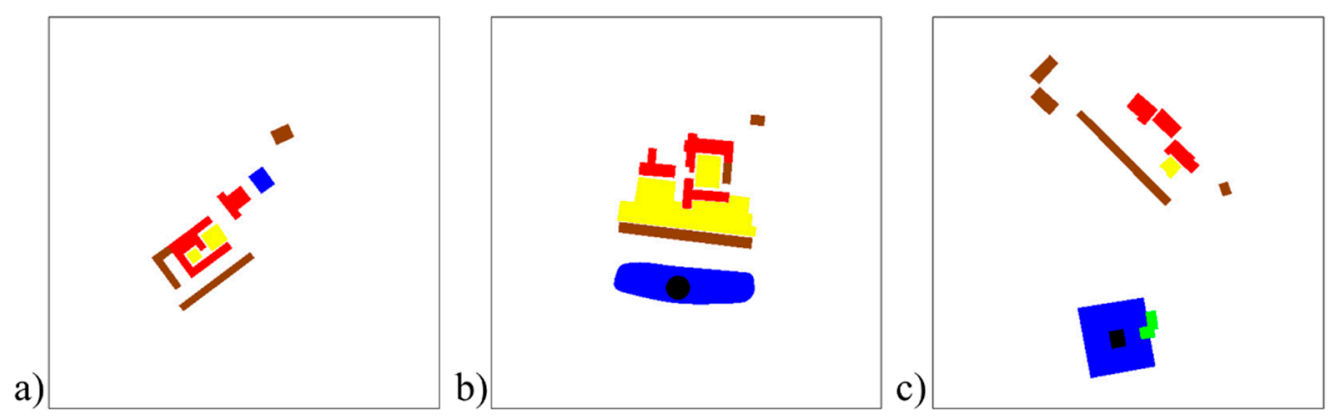

Figure 11. Examples of plans that show the trends evaluated in this research. (a) Imcheonggak, (b) Unjoru, and (c) Seongyojang (pond (PO) = blue, functional building (FB) = brown, residential building $(\mathrm{RB})=$ red, yard $(\mathrm{YA})=$ yellow).

\section{Discussion}

The purpose of this research was to conceptually prove that for the acquisition of ecological wisdom, the process of extraction (making knowledge tacit to explicit) is required for sustained knowledge creation. We proved by integrating the knowledge creation process and the knowledge-to-wisdom transformation process for ecological wisdom. Then, we demonstrated the process of externalization of ecological wisdom from the built heritage of private Korean gardens of Joseon Dynasty through a four-stage data-driven methodology. First, representative cases were defined and collected. Then, we deconstructed the cases into two aspects: Geometric data, and environmental data. For the geometric data, the garden components were digitalized and quantified using the HoF algorithm. As for the environmental data, physiography, geology, climate, and hydrology data were collected using various resources, but mainly the thematic maps in ArcGIS. Next, we calculated the similarity matrices between 35 gardens for both data types ending with a total of 29 matrices (15 matrices from geometric data and 14 matrices from environmental data). Finally, a matrix correlation was conducted using the quadratic assignment procedure (QAP) to eliminate spurious relationships, and by $3 \mathrm{D}$ plotting to identify the shared ecological knowledge for architectural configuration (or geometric layout) in relation to the environment.

As a result, we found out that surprisingly, the location of ponds varied depending on the yearly average temperature of sites. While most ponds were located in the southern direction of residential buildings, as the temperature increased, the pond location actually moved to the northeastern part of residential buildings. This is ecological wisdom that can be reused for future sustainable designs. Additionally, another wisdom learned or emphasized from the extraction is that ponds that are large in scale should be constructed when gardens are near rivers for natural circulation of hydrology.

\section{Conclusions}

We would like to draw attention to the proposed conceptual framework that incorporates the process of extraction for sustained knowledge creation as the contribution of this research and the four-stage data-driven methodology that is applicable to the analysis of other ecological designs.

As exploratory research, there are some important environmental data not covered in this research, such as wind speed and directions, as well as vegetation, even though these data are quite important regarding garden designs. The reason for this is due to that lack of accessibility to accurate data. Through more thorough research, we plan to gather more environmental data (as long as available) in future research.

In addition to dealing with the limitations pointed above in future research, there are several directions to extend this research. One is to enhance the analysis methodology by employing different space quantification method to see if results are the same or different. For instance, instead of using the term 'traditional', the term 'vernacular' opens up the choices for the possible cases to analyze for ecological wisdom because by definition, vernacular architecture or garden implies a man-made artifact 
that embodies the knowledge with the ecologic solutions for sustainability compatible with the climate and the geography [13]. Furthermore, approaching the research from the vernacular gardens allows more universal research (meaning other gardens from different cultures can be analyzed) from the perspective of the spatial analysis of the gardens with a global classification terminology for the garden's spatial structure (workspace, productive space, social space, leisure space, and formal and entry space and buffer zones) [48]. Last is to extend the scope of the research by exploring the possibilities of building an expert system that can automatically explore the most correlated environmental data with geometric data images and environmental data as input. With this, the ecological wisdom can be accumulated and eventually be able to provide ecological wisdom for designers and planners guiding the designs to be more ecological.

Author Contributions: Conceptualization, methodology, formal analysis, investigation, resources, data curation, writing—original draft preparation, writing—review and editing, visualization, A.M.; supervision, J.-H.L.

Funding: The APC was partially funded by Korea Advanced Institute of Science and Technology (KAIST).

Acknowledgments: This research would not have been possible with the help of Minwoo Lee for his technical support on the implementation of Histogram of Force algorithm, as well as similarity measures on MATLAB. In addition, the authors would like to thank the reviewers for their insightful feedbacks for further development of this research.

Conflicts of Interest: The authors declare no conflict of interest. The funders had no role in the design of the study; in the collection, analyses, or interpretation of data; in the writing of the manuscript, or in the decision to publish the results.

\section{References}

1. Todd, N.J.; Todd, J. Bioshelters, Ocean Arks, City Farming: Ecology as the Basis of Design; Sierra Club Books: San Francisco, CA, USA, 1984.

2. van der Ryn, S.; Cowan, S. Ecological Design; Island Press: Washington, DC, USA, 1995.

3. Erixon Aalto, H.; Marcus, L.; Torsvall, J. Towards a Social-Ecological Urbanism: Co-Producing Knowledge through Design in the Albano Resilient Campus Project in Stockholm. Sustainability 2018, 10, 717. [CrossRef]

4. Kates, R.W.; Clark, W.C.; Corell, R.; Hall, J.M.; Jaeger, C.C.; Lowe, I.; McCarthy, J.J.; Schellnhuber, H.J.; Bolin, B.; Dickson, N.M.; et al. Sustainability Science. Science 2001, 292, 641-642. [CrossRef] [PubMed]

5. Pickett, S.T.A.; Cadenasso, M.L. Linking ecological and built components of urban mosaics: An open cycle of ecological design. J. Ecol. 2008, 96, 8-12. [CrossRef]

6. Xiang, W.N. Ecophronesis: The ecological practical wisdom for and from ecological practice. Landsc. Urban Plan. 2016, 155, 53-60. [CrossRef]

7. Xiang, W.N. Doing real and permanent good in landscape and urban planning: Ecological wisdom for urban sustainability. Landsc. Urban Plan. 2014, 121, 65-69. [CrossRef]

8. Zheng, S.; Han, B.; Wang, D.; Ouyang, Z. Ecological Wisdom and Inspiration Underlying the Planning and Construction of Ancient Human Settlements: Case Study of Hongcun UNESCO World Heritage Site in China. Sustainability 2018, 10, 1345. [CrossRef]

9. Douglas, E.M.; Reardon, K.M.; Täger, M.C. Participatory action research as a means of achieving ecological wisdom within climate change resiliency planning. J. Urban Manag. 2018, 7, 152-160. [CrossRef]

10. Steiner, F. The ecological wisdom of plan-making. J. Urban Manag. 2018, 7, 124-130. [CrossRef]

11. Forester, J. Ecological wisdom through deliberative improvisation: Theory and practice in challenging cases. J. Urban Manag. 2018, 8, 12-19. [CrossRef]

12. Wang, Z.; Jiang, Q.; Jiao, Y. Traditional Ecological Wisdom in Modern Society: Perspectives from Terraced Fields in Honghe and Chongqing, Southwest China. In Ecological Wisdom: Theory and Practice; Yang, B., Young, R.F., Eds.; Springer: Singapore, 2019; pp. 125-148.

13. Kırbaş, B.; Hızlı, N. Learning from Vernacular Architecture: Ecological Solutions in Traditional Erzurum Houses. Procedia Soc. Behav. Sci. 2016, 216, 788-799. [CrossRef]

14. Mileto, C.; Vegas López-Manzanares, F.; Villacampa Crespo, L.; García-Soriano, L. The Influence of Geographical Factors in Traditional Earthen Architecture: The Case of the Iberian Peninsula. Sustainability 2019, 11, 2369. [CrossRef] 
15. Yoon, K.B. The Garden Culture of Korea (1): The development of Korean gardens. Korean Cult. Arts J. $1983,86$. Available online: http://www.arko.or.kr/zine/artspaper83_03/19830323.htm (accessed on 25 September 2019).

16. Kim, S.B.; Kim, E.J.; Yoon, H.J.; Kang, B.H.; Lee, S.Y. Oriental Traditional Garden Style and Characteristics. Korean J. Agric. Hist. 2009, 8, 135-155.

17. Park, K.J. Gardens of Korea; Seokyo Books: Seoul, Korea, 2015.

18. Bolton, S. Ecological Engineering: Design Principles. Encyclopedia Ecol. 2019, 493-497. [CrossRef]

19. Rowley, J. The wisdom hierarchy: Representations of the DIKW hierarchy. J. Inf. Sci. 2007, 33, 163-180. [CrossRef]

20. Maxwell, N. From knowledge to wisdom: The need for an academic revolution. Lond. Rev. Educ. 2007, 5, 97-115. [CrossRef]

21. Young, R.F. Modernity, postmodernity, and ecological wisdom: Toward a new framework for landscape and urban planning. Landsc. Urban Plan. 2016, 155, 91-99. [CrossRef]

22. Yang, B.; Li, S.; Xiang, W.N.; Bishop, I.; Liao, K.H.; Liu, J. Where Does Ecological Wisdom Come from? Historical and Contemporary Perspectives. In Ecological Wisdom: Theory and Practice; Yang, B., Young, R.F., Eds.; Springer: Singapore, 2019; pp. 33-56.

23. Virtanen, I. Externalization of Tacit Knowledge Implies a Simplified Theory of Cognition. J. Knowl. Manag. Pract. 2011, 12. Available online: http://www.tlainc.com/articl267.htm (accessed on 24 September 2019).

24. Semeon, G.; Garfield, M.; Meshesha, M. Exploring Mechanisms in Tacit Knowledge Externalization: Preliminary Findings from Participatory Agricultural Innovation Practices in Ethiopia. In Proceedings of the Twenty-first Americas Conference on Information Systems, Fajardo, Puerto Rico, 13-15 August 2015.

25. Dubberly, H.; Evenson, S. Design as learning-Or "knowledge creation"-The SECI model. Interactions 2011, 18, 75-79. [CrossRef]

26. Nonaka, I.; Toyama, R. The knowledge-creating theory revisited: Knowledge creation as a synthesizing process. Knowl. Manag. Res. Pract. 2003, 1, 2-10. [CrossRef]

27. Kabir, N.; Carayannis, E. Big data, tacit knowledge and organizational competitiveness. J. Intell. Stud. Bus. 2013, 3, 54-62. [CrossRef]

28. Wang, S.; Luo, X.; Wei, W.; Zheng, Y.; Dou, Y.; Cai, X. Calculation of Evolutionary Correlation between Individual Genes and Full-Length Genome: A Method Useful for Choosing Phylogenetic Markers for Molecular Epidemiology. PLoS ONE 2013, 8, e81106. [CrossRef] [PubMed]

29. Yeoksa Gyeonggwan Yeonguhoe (Historical Landscape Research Group). Field Note of Korean Gardens; Dongnyok: Gyeonggi-do Paju-si, Korea, 2008.

30. Presidential Commission on Architecture Policy (PCAP). Research for the Development of a Standard Model of Korean Traditional Gardens and Support Plan for the Revitalization; PCAP: Seoul, Korea, 2014.

31. Yu, R.; Gu, N.; Ostwald, M. The mathematics of spatial transparency and mystery: Using syntactical data to visualise and analyse the properties of the Yuyuan Garden. Vis. Eng. 2016, 4. [CrossRef]

32. Li, B.; Fonseca, F. TDD: A Comprehensive Model for Qualitative Spatial Similarity Assessment. Spat. Cognit. Comput. 2006, 6, 31-62. [CrossRef]

33. Uršič, P.; Tabernik, D.; Boben, M.; Skočaj, D.; Leonardis, A.; Kristan, M. Room Categorization Based on a Hierarchical Representation of Space. Int. J. Adv. Robot. Syst. 2013, 10, 94. [CrossRef]

34. Yan, H.; Li, J. Spatial Similarity Relations in Multi-Scale Map Spaces; Springer: Heidelberg, Germany, 2015.

35. Matsakis, P. Understanding the spatial organization of image regions by means of force histograms: A guided tour. In Applying Soft Computing in Defining Spatial Relations; Springer: Heidelberg, Germany, 2002; pp. 99-122.

36. Sledge, I.J.; Keller, J.M.; Song, W.; Davis, C.H. Conflation of Vector Buildings with Imagery. IEEE Geosci. Remote Sens. Lett. 2011, 8, 83-87. [CrossRef]

37. Panteras, G.; Clark, J.R.; Agouris, P.; Stefanidis, A. Ontology-driven scene interpretation based on qualitative spatial reasoning. GeoJournal 2017, 82, 751-768. [CrossRef]

38. Yang, B.; Li, S. Design with Nature: Ian McHarg's ecological wisdom as actionable and practical knowledge. Landsc. Urban Plan. 2016, 155, 21-32. [CrossRef]

39. National Spatial Data Infrastructure Portal. Available online: http://data.nsdi.go.kr/dataset (accessed on 17 July 2019).

40. Climate-Data.Org. Available online: https://ko.climate-data.org/ (accessed on 24 July 2019).

41. McCune, B.; Grace, J.B.; Urban, D.L. Chapter 6: Distance Measures. In Analysis of Ecological Communities; MjM Software: Gleneden Beach, OR, USA, 2002; pp. 45-58. 
42. Hanneman, R.A.; Riddle, M. Chapter 18: Some Statistical Tools. Introduction to Social Network Analysis. Available online: https://faculty.ucr.edu/ \{\}hanneman/nettext/Introduction_to_Social_Network_Methods.pdf (accessed on 22 August 2019).

43. Lee, W.J.; Lee, W.K.; Sohn, S.Y. Patent Network Analysis and Quadratic Assignment Procedures to Identify the Convergence of Robot Technologies. PLoS ONE 2016, 11, e0165091. [CrossRef]

44. Krackardt, D. QAP partialling as a test of spuriousness. Soc. Netw. 1987, 9, 171-186. [CrossRef]

45. Simpson, W.B. QAP: The Quadratic Assignment Procedure. In Proceedings of the North American Stata Users' Group Meeting, Boston, MA, USA, 20-21 March 2001; Available online: http://fmwww.bc.edu/RePEc/ nasug2001/simpson.pdf (accessed on 22 August 2019).

46. Anderson, B.S.; Butts, C.; Carley, K. The interaction of size and density with graph-level indices. Soc. Netw. 1999, 21, 239-267. [CrossRef]

47. Butts, C.T. SNA: Tools for Social Network Analysis; R Package Version 2.4. 2016. Available online: https://CRAN.R-project.org/package=sna (accessed on 24 September 2019).

48. Roberts, J. Researching the vernacular garden. Landsc. Res. 1996, 21, 175-187. [CrossRef]

(C) 2019 by the authors. Licensee MDPI, Basel, Switzerland. This article is an open access article distributed under the terms and conditions of the Creative Commons Attribution (CC BY) license (http://creativecommons.org/licenses/by/4.0/). 